\title{
Risk Management Of Supplier-Buyer In Procurement Of Raw Materials For Improving Supply Chain Performance
}

\author{
Dwi Iryaning Handayani \\ Industrial Engineering Department \\ Faculty of Engineering Panca Marga University Probolinggo \\ Yos Sudarso street 107 Pabean Dringu Probolinggo \\ dwiiryaninghandayani@yahoo.co.id
}

\begin{abstract}
This study discusses the relationship between Supplier and Buyer related to the procurement of raw materials. In the establishment of Supplier-Buyer relationship, there are considerable risks including coordination problems in supplying, demanding, and disruption of normal activities. Therefore, in overcoming the risks occurring in the Supplier-Buyer, it is necessary to have risk management approach of Supplier-Buyer relationship in Supply Chain activity, to know the occurrence of potential risks for improving Supply Chain performance. This study aims to analysis risk management on Supplier-Buyer relationship for improving company performance by identifying, assessing risks on raw material procurement and evaluating as well as mitigating potential risks that occur to improve Supply Chain performance. The methods of the study are SCOR, FMEA and TOPSIS, and Supplier performance matrix. As the results of SCOR performance, there are two risks of Internal Facing and four risks of Customer Facing. The risks that are categorized as customer facing are supplier risks with Continuity of supply, on time delivery, Knowledge resource and Quality risk categories. While, the Internal facing risks, risks which are associated to buyers including accident and knowledge resource risk categories. The proposed mitigation for improving Supplier performance, a) Coordination with suppliers in the form of sharing information between buyers and suppliers, b) Implementation of Supplier Relationship Management and e-SRM (Electronic-Supplier Relationship Management)
\end{abstract}

Keywords : Risk, Supplier, Buyer, Performance, Supply Chain

\section{BACKGROUND}

Supply Chain Disruptions are unplanned events in Supply Chain which have impacts on the materials and company performance, those impacts are varies, therefore the countermeasures are expensive. (Schmidt William, 2012). Besides having impacts on the company performance, Supply Chain Disruptions also have impacts on the Supply Chain performance which results in various problems such as the length of lead time, stock out, inability to meet the customers' demands and the increasing of costs. To overcome various problems which occur in the flow of Supply Chain, companies must make some improvements continuously, for example by maintaining good relationship with Suppliers, it is due to the fact that Suppliers have an important role in providing raw materials and as the main determinant in producing products for the survival of a company. (Handayani, 2015).

The establishment of a good relationship between Suppliers and Buyers will provide benefits for the company because if there is an unexpected environmental change, the 
company will be better prepared. In addition, the success of managing the relationship of Supplier-Buyer provides benefits for the companies to sell their products punctually without any stock vacuity in the market. (Liu et al, 2010). Similarly, (Elmuti et al, 2008) states that Supplier- Buyer relationship can give better respond to customers' needs.

However, according to Kleindorfer and Saad (2005) there are some considerable risks in establishing Supplier-Buyer relationship, including coordination problems in supplying, demanding and the disruption of normal activities. High dependence on Suppliers causes risks to the Supply Chain network (Punniyamoorty, 2013). Likewise, the delays of raw materials delivery become the cause of risk for Supply Chain which can inhibit production process activities. (Handayani, 2016). Uncertainty and irregularities in the raw material Supply are the causes of risks. If we neglect the condition without giving any solutions, the Supply Chain performance will decline, (Tuncel dan Alpan, 2010). Thus, to overcome the risks which occur between Supplier-Buyer, there must be risk management approach for Supplier-Buyer relationship in Supply Chain activities in order to know the occurrence of potential risks, which finally can improve Supply Chain performance.

This study aims to analysis risk management on Supplier-Buyer relationship for improving company performance by identifying, assessing risks on raw material procurement and evaluating as well as mitigating the occurrence of potential risks in order to improve Supply Chain performance.

\section{THEORETICAL REVIEW}

Supply Chain Risk Management. Supply Chain Risk Management (SCRM) is a combination of the concept of Supply Chain Management and Risk Management. While risk is a function of the level uncertainty and the impact of an event. Risk according to (Australian / New Zealand Standard) is a possibility that an unwanted event will affect the goal. So that risk management is a process for knowing, analyzing and controlling risk in every activity or activity of a company.

Marhavilas (2011) explained risk assessment as a systematic process in measuring the impact of events and consequences due to human activities in a dangerous environment. A complex model of interaction between humans, the machine will be overshadowed by failure so there is a need for risk analysis to reduce and avoid these failures. Application of risk management in this study to determine the factors that can trigger a system failure.

Relationship between Supplier and Buyer. The relationship between Supplier and Buyer is one of the successes in managing Supply Chain by sharing information among others and choosing Supplier. Supplier and Buyer Relations can improve the company's operational performance (Ryu et al., 2009; Anbanandam et al., 2011) and the increasing response to consumer demand. The key factors of success in building supplier relationships are 1) Commitment, 2) Trust, 3) Interdependence.

Commitment and trust are the main factors that support corporate collaboration with suppliers (Stevani et.al, 2014). With a commitment, it can support the relationship between suppliers and buyers that are effective and provide a spirit of cooperation to form stronger relationships (Salam, 2011). 
Failure Mode and Effect Analysis (FMEA) and TOPSIS (Technique for Order by Similarity to Ideal Solution). Failure Modes and Effect Analysis (FMEA) is a popular method in supply chain risk management (Vanany et al., 2009). FMEA is used to determine risk priorities in the management process (Segismundo and Miguel, 2008). FMEA is one of the most widely used techniques in risk analysis to identify failure modes and predict impacts and relevance. The main purpose of FMEA is to analyze in identifying, prioritizing, and preventing potential failures of the system, design or process before being offered to consumers. Assessment parameters for risks include impacts (Severity), occurrence and detection.

Severity, occurrence and detection determination is done using an assessment questionnaire. The scale used is a scale of 1-10, the greater the value of a parameter the greater the level of risk that occurs. Severity (S) states the level of seriousness of the effects that occur and as a result of the risk of potential if risk in a particular process or activity (Marimin, 2013). Severity assessment uses values (1) to (10) according to their severity. Value (1) has meaning never happened while value (10) gives an understanding that the possibility of a failure or disaster is very large and very difficult to avoid. In measuring the severity based on the seriousness of the condition of the disaster or the failure caused is called the Failure Effect.

Occurrence $(\mathrm{O})$ states the possibility of Cause and Failure Mode occurring, as a cause of potential risk in each process or activity that will be measured by the value of possible risk (Marimin, 2013). Detection (D) states the level of difficulty to detect Cause and Failure Mode. Indicates the level of opportunity that is not detected from the cause of disaster or failure. For assessment Detection uses the same scale as Severity, namely (1) to (10) the difference lies in the meaning of the number. Value (1) means that the chance to be detected is very low, while the value (10) of the opportunity escapes the control in other words it is not detected so high.

The TOPSIS method is one of the decision-making multi criteria methods based on alternative choices that have the closest rarely based on positive ideals and the farthest distance based on negative ideals. This method has advantages in calculating the relative performance of decision alternatives in a simple mathematical form (Kusumadewi, 2006).

\section{Risk Category}

Table 1. Definition of Risk Categories

\begin{tabular}{|c|c|c|}
\hline No & Risk Type & Understanding \\
\hline 1 & Quality & $\begin{array}{l}\text { The supplier's capability in delivering the right product is desired } \\
\text { by the company }\end{array}$ \\
\hline 2 & Cost & Overall costs incurred by the company \\
\hline 3 & On time delivery & The ability of suppliers to deliver goods on time \\
\hline 4 & $\begin{array}{l}\text { Production } \\
\text { capabilities }\end{array}$ & $\begin{array}{l}\text { The ability of suppliers to meet customer demand both in quantity } \\
\text { and time }\end{array}$ \\
\hline 5 & Flexibility & $\begin{array}{l}\text { The supplier's ability to fulfill demand in the event of a change of } \\
\text { order by the company }\end{array}$ \\
\hline 6 & Knowledge resource & The ability to gather convey information \\
\hline 7 & $\begin{array}{l}\text { Management related } \\
\text { issues }\end{array}$ & Policies in managing suppliers are related to taking \\
\hline
\end{tabular}


Handayani: Risk Management of Supplier-Buyer in Procurement of Raw Materials...

\begin{tabular}{cll}
\hline 8 & Accidents & Accidents that occur due to nature or humans \\
9 & $\begin{array}{l}\text { Market strength } \\
10\end{array}$ & $\begin{array}{l}\text { Continuity of supply } \\
\text { Availability of raw materials related to the dependence of major } \\
\text { suppliers }\end{array}$ \\
$\begin{array}{ll}\text { Natural man-made } \\
\text { disaster }\end{array}$ & Events caused by nature and human hands \\
\hline
\end{tabular}

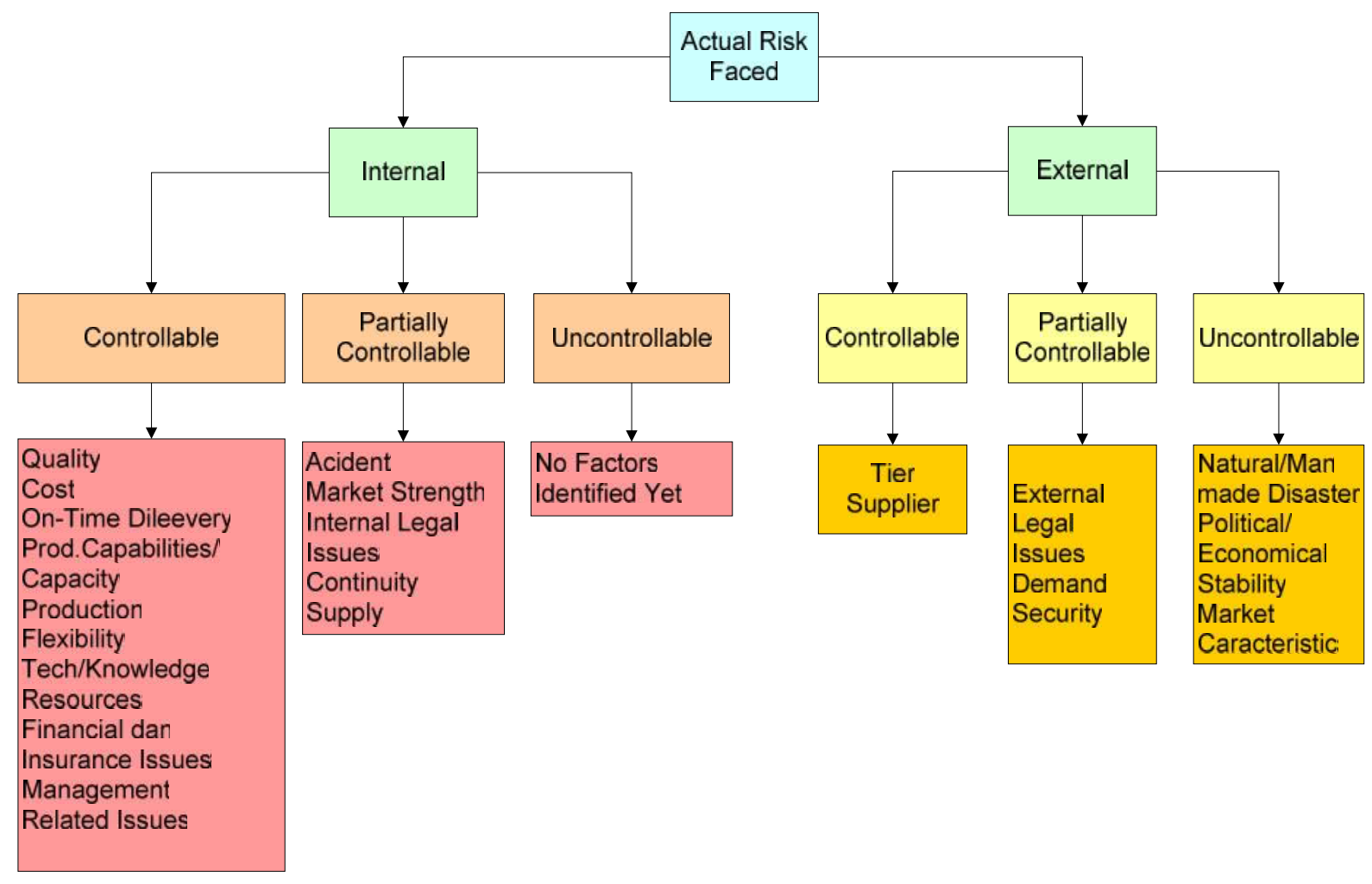

Figure 1. Risk classification and type of supply risk (Wu et al., 2006)

\section{METHOD}

This research was conducted in a disguised company (named as X company as its own request). The research was initiated by having literature study in relation to risk management theory, procurement process of raw materials, Supplier-Bayer relationship, the measurement of Supplier performance. For the existence of data, they were directly obtained by researchers from the interviews and questionnaires or from the data which are already available in a company or from the company documents.

Respondents in this study are those who work in companies at the field of Logistics, Production Planning and Control who have good knowledge about company relationship with the Suppliers such as administrative staff, supervisors and managers. There are two stages in doing this research, namely:

The first stage analysis Supplier-Buyer relationship by doing risks management approach as follows: 
a) Identifying business process in procurement of raw materials at the company. Business process at this stage is using SCOR (Supply Chain Operation Reference) model by mapping the process based on five parameters, namely Plan, Source, Delivery and Return. The mapping process is conducted in order to know the potential risks of each stage at the process of procuring raw materials.

b) Identification risks of each process. Risks identification is carried out at each stage in the procurement process of raw materials which refers to the designing result of SCOR business process. The goal of doing this stage is to find out how much the potential risks of each stage at the process in procuring raw materials. Technique that is used in analysis risk events at each stage of the process is applying $5 \mathrm{~W} 1 \mathrm{H}$ principle, however this research only applied $3 \mathrm{~W} 1 \mathrm{H}$ (what, where and how). How to implement $3 \mathrm{WIH}$ in exploring potential risks begin with a question about what the causes of the risks are, the next question relates to the location of potential risks or where the risks occur, then by asking why the risks occur, and the last question is how the potential risks can occur. This stage is aimed to indicate the potential risks and the causes of risks to the Supplier-Buyer in the procurement of raw materials.

c) Risks assessment by using FMEA and MADM (Multi Attribute Decision Making) methods, namely Technique For Order Preference By Similarity To Ideal Solution (TOPSIS)

d) Risks evaluation by using metric system of model SCOR performance by referring to Supplier performance attributes, namely Reliability, Responsiveness, Flexibility, Cost and Asset Management.

f) Risks Mitigation are carried out for the top 6 risks which have high values. At this Risks Mitigation, there are some steps that need to be done: by knowing the causes of risks, correction of risk causes and then mitigation plans that must be carried out by the company in order to improve Suppliers performances.

\section{THE RESULTS}

Identification of Supply Chain structure and its flow. Supply Chain structure consists of members who are interrelated. Supply Chain members are those who directly involved in Supply Chain activities (Chopra,et.al 2009). The identification of Supply Chain structure is carried out by having direct interviews with relevant people in order to get an overview of $\mathrm{X}$ company which produces cardboards or cardboard boxes. The network structure in X company consists of Supplier-Manufacture-Consumers.

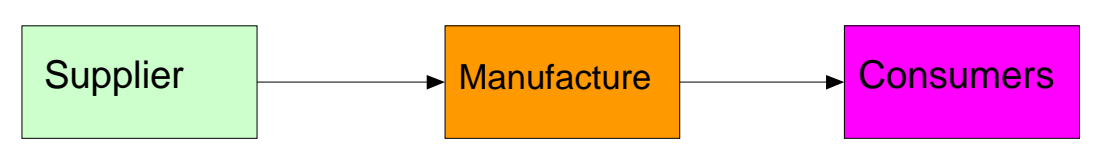

Figure 2. Supply Chain network structure 


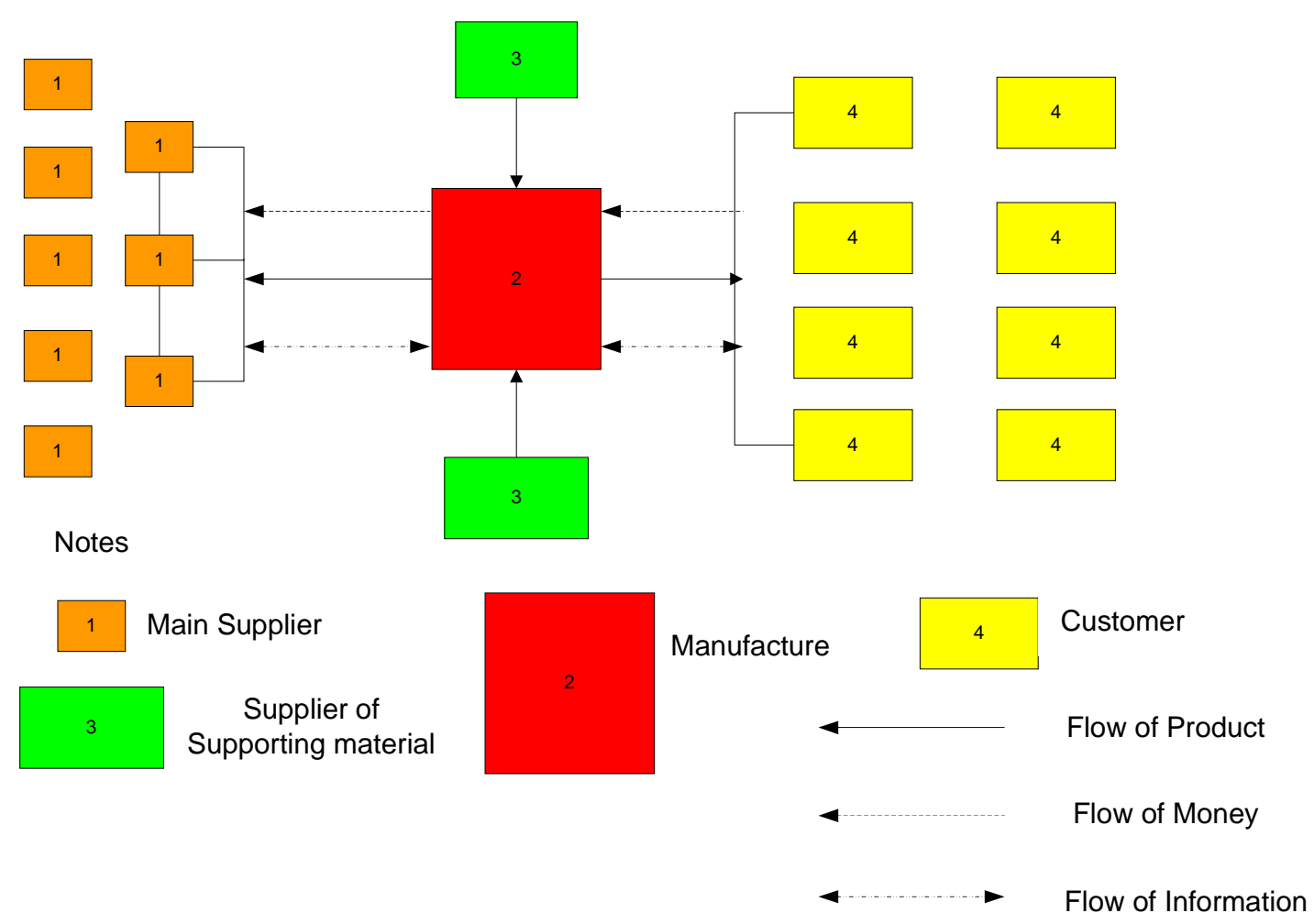

Figure 3. Flowing pattern of Supply Chain for cardboard products

X company deals with Supplier of main raw material and Supplier of supporting raw material, main raw materials consist of papers while supporting raw materials consist of glue and ink. Meanwhile, the consumers of $X$ company are consumers who produce various products. The numbers of the consumers are constantly twenty eight consumers. On figure 2 Supply Chain network structure consists of the flow of finished products and raw materials, the flow of information and financial. Whereas figure 3 is the flowing pattern of supply chain which contains the flow of products, information and money.

Identification of the raw materials procurement activities based on business process. Identification stage of the raw materials procurement activities is using SCOR method (Pujawan, 2010). The SCOR model divides five kinds of areas, namely: Plan, Source, Make, Delivery, Return (Supplier and consumers), This study applied three types of process, they are Plan, Source and Return as follows: 1) Plan is a process of balancing the demand and the supply to meet the necessity. 2) Source is a procedure for procuring goods and services to fulfil the demands. 3) Return is a way of making and receiving return due to various reasons. Description on the procurement of raw materials activities based on business process is clearly explained in Table 2 
Table 2. The procurement of raw materials activities based on business process

\begin{tabular}{|c|c|c|}
\hline Types of Process & Process Categories & Business Process \\
\hline PLAN & Purchasing of Raw Materials & $\begin{array}{l}\text { Controlling the stocks in warehouse } \\
\text { Production plan }\end{array}$ \\
\hline \multirow[t]{6}{*}{ SOURCE } & & Negotiation with Supplier \\
\hline & Ordering of Raw materials & Contract with Supplier \\
\hline & & Delivering purchase order to Supplier \\
\hline & Receiving of Raw Material & $\begin{array}{l}\text { The unloading and Checking of raw } \\
\text { materials }\end{array}$ \\
\hline & & $\begin{array}{l}\text { The receiving of raw materials } \\
\text { Payment }\end{array}$ \\
\hline & Raw materials delivery & Storage of goods in the warehouse \\
\hline RETURN & Returning of Raw materials & Delivery of products \\
\hline
\end{tabular}

There are some activities at the Plan process, namely: production planning, materials procurement planning. The checking of the availability of raw materials in warehouse as well as the checking of cardboard products aims to determine the level of finished product stocks in the warehouse. It is related to the production planning in determining the amount of productions based on the amount of demands at the time. In addition, the amount of production is also related to the planning of main materials and supporting materials procurement which has relation to Source activities.

The second activity is Source which is initiated by negotiating with suppliers, contract with suppliers and then the delivering of Purchase Order to suppliers and finally, the receiving of materials from the suppliers in a company. The last activity is Return activity. There are two activities at this stage, namely the return of materials to suppliers and the return of products from consumers. For the former activity, namely the return of materials to suppliers, it is done by the company if there is Reject at the receiving of material during the inspection process. While for the later, namely the return of products from consumers.

Risk Identification which affects Supply Chain performance. This stage identifies the risks that occur at implementation business process of procuring raw materials. The risks that occur at Table 3 is probability of events which happens during a period of time that have some impacts on undesired events. (Faizal, 2014). The occurrence of risks at a company can not be avoided or eliminated, however it can be carried out and managed well so that the risks can be minimized by mitigation or some actions which minimize the risks impacts and their probabilities, (Kayis dan Karningsih, 2012). For those reasons, risks management approach is carried out at an early stage of identifying, assessing, analysis, and managing the potential of risks in supply chain activities (Trkman dan McCormack, 2009), thus the structural process for assessing the risks and measuring their effects and consequences at the occurrence of dangerous risks can be obtained. (Marhavilas, 2011). 
Table 3. Risk Identification of Supply Chain performance The procurement of Materials

\begin{tabular}{|c|c|c|}
\hline No & Business Process & Risks \\
\hline 1 & The stocks in warehouse & $\begin{array}{l}\text { The occurrence of planning fault on raw } \\
\text { materials need } \\
\text { Sudden changes on materials planning }\end{array}$ \\
\hline 2 & Production Planning & $\begin{array}{l}\text { Sudden High Demands } \\
\text { Sudden changes on production plans } \\
\text { There is no price agreement of raw materials } \\
\text { between the suppliers and the company }\end{array}$ \\
\hline 3 & Negotiation with Suppliers & $\begin{array}{l}\text { The unavailability of raw materials needed by } \\
\text { the company } \\
\text { The inhibition of negotiation }\end{array}$ \\
\hline 4 & Contract with Suppliers & $\begin{array}{l}\text { Suppliers do not comply the previous } \\
\text { agreement at contract } \\
\text { The decline of suppliers performance }\end{array}$ \\
\hline 5 & $\begin{array}{l}\text { Delivering Purchase Order to } \\
\text { Supplier }\end{array}$ & The delay of Purchase Order delivery \\
\hline 6 & Weighing trucks at truckscale & $\begin{array}{l}\text { The final weight is different from the weight } \\
\text { from suppliers }\end{array}$ \\
\hline 7 & $\begin{array}{l}\text { Unloading and checking of } \\
\text { raw material }\end{array}$ & $\begin{array}{l}\text { There is inequality of the quantity between } \\
\text { delivered products and the number of } \\
\text { products ordered by the company }\end{array}$ \\
\hline 8 & Receiving of Materials & $\begin{array}{l}\text { Raw materials received are different from the } \\
\text { previous order } \\
\text { Paper materials are blemished and spotted } \\
\text { Fish eye defect, twisted and dented }\end{array}$ \\
\hline 9 & Payment & $\begin{array}{l}\text { The mistake in writing the amount of raw } \\
\text { materials at delivery orders }\end{array}$ \\
\hline 10 & $\begin{array}{l}\text { Storage of goods in the } \\
\text { warehouse }\end{array}$ & $\begin{array}{l}\text { The leak in the warehouse in raining } \\
\text { The fire of warehouse which contains raw } \\
\text { materials }\end{array}$ \\
\hline 11 & Delivery of Product & $\begin{array}{l}\text { There is a disaster } \\
\text { There is a traffic accident } \\
\text { There is no service/ means of transportation in } \\
\text { delivering raw materials } \\
\text { Incompatibility of time in delivering all raw } \\
\text { materials with the previous schedule }\end{array}$ \\
\hline
\end{tabular}

The result of risk identification in Table 3 indicates the way to identify the potential risks for the critical process. The stage of risks identification including the data of risk events at each stages of process in buying raw materials which has been checked and selected by Expert of the company. The Expert will select the significant risks occurred at the business process. Moreover the filling out of questionnaire, discussion and interview with the Expert will be conducted. 
Classification of Risk Categories. The classification of risks according to ( $\mathrm{Wu}$ et al, 2006) is divided into nine risk categories, and from the identified risk categories, there are two dominant categories, namely Knowledge Resource and Quality with nine risks for the Knowledge Resource and six risks for Quality. Knowledge Resource is an ability to collect and convey information from manufacture to suppliers or otherwise from supplier to manufactures in procurement process of raw materials. Whereas the common potential risks for the quality of paper raw materials are blemished, fish eye defect, twisted, dented and spotted. Thus, the company carries out additional process to overcome the conditions, as a consequence, it will add more cost and time than it should be.

Table 4. Categories and kinds of Supplier-Buyer Risks

\begin{tabular}{|c|c|c|}
\hline Risk Categories & Kind of Risks & \\
\hline \multirow[t]{3}{*}{ Quality } & $\begin{array}{l}\text { Raw materials received are different from the } \\
\text { previous order }\end{array}$ & R1 \\
\hline & $\begin{array}{l}\text { Paper raw materials received are blemished and } \\
\text { spotted }\end{array}$ & $\mathrm{R} 2$ \\
\hline & There are fish eye defect, twisted and dented & R3 \\
\hline \multirow[t]{3}{*}{ Accident } & The leak in the warehouse in raining & R4 \\
\hline & The fire of warehouse which contains raw materials & $\mathrm{R} 5$ \\
\hline & There is a traffic accident & R6 \\
\hline Cost & $\begin{array}{l}\text { There is no price agreement of raw materials } \\
\text { between the suppliers and the company }\end{array}$ & $\mathrm{R} 7$ \\
\hline On time delivery & $\begin{array}{l}\text { Incompatibility of time in delivering all raw } \\
\text { materials with the previous schedule }\end{array}$ & $\mathrm{R} 8$ \\
\hline $\begin{array}{l}\text { Natural man- } \\
\text { made disaster }\end{array}$ & There is a disaster & R9 \\
\hline $\begin{array}{l}\text { Continuity of } \\
\text { supply }\end{array}$ & $\begin{array}{l}\text { The unavailability of raw materials needed by the } \\
\text { company }\end{array}$ & $\mathrm{R} 10$ \\
\hline \multirow[t]{9}{*}{$\begin{array}{l}\text { Knowledge } \\
\text { resource }\end{array}$} & $\begin{array}{l}\text { The occurrence of planning fault on raw materials } \\
\text { need }\end{array}$ & $\mathrm{R} 11$ \\
\hline & Sudden changes on materials planning & $\mathrm{R} 12$ \\
\hline & Sudden High Demands & R13 \\
\hline & Sudden changes on production plans & R14 \\
\hline & $\begin{array}{l}\text { The mistake in writing the amount of raw materials } \\
\text { at delivery orders }\end{array}$ & $\mathrm{R} 15$ \\
\hline & The delay of Purchase Order delivery & R16 \\
\hline & $\begin{array}{l}\text { Suppliers do not comply the previous agreement at } \\
\text { contract }\end{array}$ & $\mathrm{R} 17$ \\
\hline & $\begin{array}{l}\text { There is inequality of the quantity between the } \\
\text { delivered products and the number of products } \\
\text { ordered by the company }\end{array}$ & $\mathrm{R} 18$ \\
\hline & $\begin{array}{l}\text { The final weight is different from the weight from } \\
\text { suppliers }\end{array}$ & $\mathrm{R} 19$ \\
\hline $\begin{array}{l}\text { Natural man- } \\
\text { made disaster }\end{array}$ & There is a disaster & \\
\hline Management & The decline of suppliers performance & $\mathrm{R} 20$ \\
\hline \multirow[t]{2}{*}{ related issues } & The inhibition of negotiation & $\mathrm{R} 21$ \\
\hline & $\begin{array}{l}\text { There is no service/ means of transportation in } \\
\text { delivering raw materials }\end{array}$ & $\mathrm{R} 22$ \\
\hline
\end{tabular}


Identification on Impacts of Risks that Affect Supply Chain Performance. After the risks which affect the supply chain performance of the company have been identified, the next step is identifying the impacts of each risks. Table 5 illustrates the impact of risks that affect Supply Chain performance.

Table 5. The impacts of Risks that affect Supply Chain Performance

\begin{tabular}{|c|c|c|c|}
\hline No & The Impacts of Risks & No & The Impacts of Risks \\
\hline 1 & The excess of raw materials & 13 & Lack response to the company demand \\
\hline 2 & The lack of raw materials & 14 & The Change in delivery schedule \\
\hline 3 & Supplier can not fulfil the demand & 15 & The return of raw materials to suppliers \\
\hline 4 & The change in production schedule & 16 & $\begin{array}{l}\text { The production process does not run } \\
\text { smoothly }\end{array}$ \\
\hline 5 & The change in raw material Order & 17 & An inventory happens \\
\hline 6 & Working overtime & 18 & Lack of credibility to suppliers \\
\hline 7 & $\begin{array}{l}\text { The change in the amount of raw } \\
\text { materials that have been ordered }\end{array}$ & 19 & $\begin{array}{l}\text { The existence of additional production } \\
\text { cost }\end{array}$ \\
\hline 8 & The change in production schedule & 20 & The length of lead time \\
\hline 9 & There are neglected demands & 21 & Raw materials damage \\
\hline 10 & $\begin{array}{l}\text { The discontinue of production } \\
\text { process }\end{array}$ & 22 & The discontinue of production process \\
\hline 11 & The company got loss & 23 & $\begin{array}{l}\text { The delay in fulfilling consumers' } \\
\text { demands }\end{array}$ \\
\hline 12 & The delay of delivery & 24 & The delay of delivery \\
\hline
\end{tabular}

From the twenty four risks, there are six dominant impacts of risks such as: The lack of raw materials, the unfulfilling demands, the loss of the company, the return of raw materials to suppliers, lack of credibility to supplier, The existence of additional production cost.

Supplier and Buyer relationship is one of the success to improve Supply Chain performance by sharing information between Supplier and Buyer (Ryu et al., 2009; Anbanandam et al., 2011). In addition, the factor of 1) Commitment, 2) Trust, 3) Interdependensi are the factors of success in making relationship with supplier (Stevani et.al, 2014). It is proved by Salam's statement (2011) which says that commitment can support the effective relationship between Supplier and Buyer, moreover it can also empower the spirit of cooperation for having stronger relationship.

Risks Assessment. After the risk and their impacts which can affects Supply Chain performance of the company have been identified, the Risk Priority Index calculation is carried out in order to find solution in improving Supply Chain performance. The risks assessment is done by integrating FMEA and TOPSIS method, FMEA technique is used to identify and diminish the failures of a process. Failure Modes and Effect Analysis (FMEA) is one of popular method in supply chain management (Vanany et al., 2009). FMEA is used in determining risk priority at the management process (Segismundo and Miguel, 2008).

The parameter used in FMEA method is aimed to estimate potential of risks by looking at the scores of Risk Potential Number (RPN) which are obtained by mutiplying the probability of risk events, the effects of the damage and risks detection (Ulfa, 2016). The determination of Severity, Occurrence and Detection is carried out by using 
assessment questionnaires. In this case, the range 1-10 is used, which means the bigger the scores of the parameter, the bigger the risk levels will be. Severity (S) states the level of seriousness of the occurring effects and as a result of potential risks in a particular processes or activities (Marimin, 2013).

Severity assessment is using (1) up to (10) scores according to the level of severity. Score (1) means never happen, while score (10) indicates that the probability of a failure or disaster is very large and it is very difficult to avoid. Measuring the level of severity based on the serious condition of the disaster or failure occurrence is called as Failure Effect. Occurrence $(\mathrm{O})$ indicates the probability of Cause and Failure Mode which occur, as a cause of potential risks occurrence at each process or activity which is measured by the score of possible risks (Marimin, 2013). Detection (D) indicates the severity to detect Cause and Failure Mode. Indicating the level of undetected opportunity from the causes of disasters or failures. The Detection assessment is using the same range as Severity namely (1) up to (10) which are only different at the meaning of the numbers. Score (1) means the opportunity of being detected is very low, while score (10) the opportunity of being out of control or undetected is very high.

TOPSIS method is one of Multi Criteria Decision Making method that is used to calculate the weight of each risks by referring to alternative options which has the closest distance based on positive ideals and the farthest distance based on the negative ideals. This method has an advantage in calculating relative performance of decision alternatives in the form of simple mathematics (Kusumadewi, 2006).

Table 6. The Calculation of Risk Priority Index

\begin{tabular}{|c|c|c|c|c|}
\hline Risks & $\mathrm{d}+$ & d- & $\begin{array}{l}\text { RPI }= \\
\frac{d i^{-}}{d i^{+}+d i^{-}}\end{array}$ & Rank \\
\hline The unavailability of raw & & & & 1 \\
\hline materials needed by the company & 3,828278 & 13,39476 & 0,777723 & \\
\hline $\begin{array}{l}\text { The fire of warehouse which } \\
\text { contains raw materials }\end{array}$ & 10,40391 & 11,39299 & 0,522689 & 2 \\
\hline Incompatibility of time in & & & & 3 \\
\hline $\begin{array}{l}\text { delivering all raw materials with } \\
\text { the previous schedule }\end{array}$ & 9,596388 & 9,330655 & 0,49298 & \\
\hline The occurrence of planning fault & & & & 4 \\
\hline on raw materials need & 10,117 & 8,993957 & 0,470618 & \\
\hline $\begin{array}{l}\text { Sudden changes on materials } \\
\text { planning }\end{array}$ & 8,566851 & 6,949211 & 0,447872 & 5 \\
\hline Paper raw materials received are & & & & 6 \\
\hline blemished and spotted & 11,07899 & 4,621492 & 0,294354 & \\
\hline Sudden High Demands & 12,30359 & 4,432149 & 0,264831 & 7 \\
\hline $\begin{array}{l}\text { There is no service/ means of } \\
\text { transportation in delivering raw } \\
\text { materials }\end{array}$ & 13,61549 & 4,229416 & 0,23701 & 8 \\
\hline $\begin{array}{l}\text { There are fish eye defect, twisted } \\
\text { and dented }\end{array}$ & 12,21517 & 3,104332 & 0,202639 & 9 \\
\hline $\begin{array}{l}\text { The delay of Purchase Order } \\
\text { delivery }\end{array}$ & 13,52623 & 2,291248 & 0,144855 & 10 \\
\hline
\end{tabular}




\begin{tabular}{|c|c|c|c|c|}
\hline Risks & $d+$ & d- & $\begin{array}{l}\text { RPI }= \\
\frac{d i^{-}}{d i^{+}+d i^{-}}\end{array}$ & Rank \\
\hline Raw materials received are & & & & 11 \\
\hline different from the previous order & 14,44155 & 1,141443 & 0,073249 & \\
\hline The leak in the warehouse in & & & & 12 \\
\hline raining & 14,44155 & 1,141443 & 0,073249 & \\
\hline $\begin{array}{l}\text { Sudden changes on production } \\
\text { plans }\end{array}$ & 14,58463 & 0,755191 & 0,049231 & 13 \\
\hline $\begin{array}{l}\text { There is no price agreement of } \\
\text { raw materials between the }\end{array}$ & & & & 14 \\
\hline suppliers and the company & 14,81479 & 0,663914 & 0,042892 & \\
\hline $\begin{array}{l}\text { The final weight is different from } \\
\text { the previous weight from }\end{array}$ & & & & 15 \\
\hline suppliers & 15,12704 & 0,506252 & 0,032383 & \\
\hline There is a disaster & 14,94423 & 0,429531 & 0,027939 & 16 \\
\hline $\begin{array}{l}\text { Suppliers do not comply the } \\
\text { previous agreement at contract }\end{array}$ & 14,94423 & 0,429531 & 0,027939 & 17 \\
\hline $\begin{array}{l}\text { There is inequality of the quantity } \\
\text { between the delivered products } \\
\text { and the number of products }\end{array}$ & 14,94423 & 0,429531 & 0,027939 & 18 \\
\hline There is a traffic accident & 15,25383 & 0,002561 & 0,000168 & 19 \\
\hline $\begin{array}{l}\text { The mistake in writing the } \\
\text { amount of raw materials at } \\
\text { delivery orders }\end{array}$ & 15,25383 & 0,002561 & 0,000168 & 20 \\
\hline $\begin{array}{l}\text { The decline of suppliers } \\
\text { performance }\end{array}$ & 15,25383 & 0,002561 & 0,000168 & 21 \\
\hline The inhibition of negotiation & 15,25383 & 0,002561 & 0,000168 & 22 \\
\hline
\end{tabular}

From the calculation results of Risks Priority Index or RPI at Table 5, it is clear that the first rank or the highest score is at the supplier risks that can not provide the raw materials needed. The risks are regarded as Continuity of supply, which have bad impacts for the company and they may affect to the fulfilment on consumers' demands accurately and quickly.

Risk Evaluation which affects Supplier Performance. Risk Evaluation divides all risks into three categories, they are high, medium and low risks. High risks level must be managed and they must also get special attention from management, while for medium risk level, there should be the one who has responsibility to manage them. Whereas for low risk level, they should be controlled by daily procedure. After the risks have been assessed, some strategies are applied to manage the risks. They include transferring the risks, taking the risks, eliminating the risks, reducing the risks and grouping the risks into individual level for further analysis. At the high risk level, there are 3 risks, namely the unavailability of raw materials, the fire of warehouse which contains raw materials, incompatibility of time in delivering raw materials.

The unavailability of raw materials needed by the company is the risk with the highest score, that is 0.77 . It happens because suppliers do not store the raw materials due 
to the policy which minimize the storage of materials. Thus the suppliers can not fulfil the demands of the company on the raw materials needed. As a consequence, it affects the continuity of production process and the demands can not be served well. The complete description will be completely described at figure 3 .

The risk on the fire of warehouse which contains raw materials is regarded as accident category due to the natural causes or human ones, or the occurrence of unplanned events, the impacts of the risk on the fire of warehouse cause long lead time and the loss of the company. While the risks on the incompatibility of time in delivering raw materials can affect the normal flow of raw materials, the risks may be caused by natural disaster, such as flood, the transportation does not run smoothly so that the risks which occur along supplier-buyer flow can damage supply chain performance. Overall, supply chain (supply chain disruptions) are the causes of many problems, for instance the length of lead time, stock out, inability to meet the customers' demands and the increasing of costs.

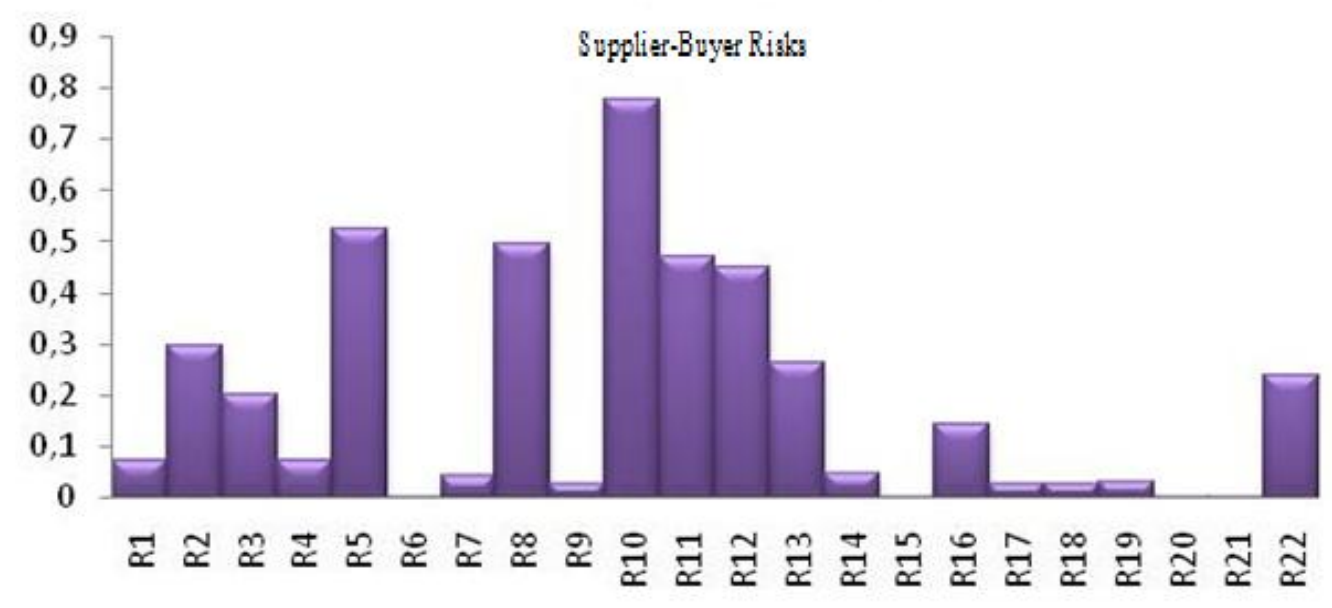

Figure 3. The chart of Risk Priority Index

The next risks evaluation is applying metric system of model SCOR performance by referring to the attribute of supplier performance including Reliability, Responsiveness, Flexibility, Cost and Asset Management (Supply Chain Council, 2006). Reliability is a superiority in implementing the agreement to supply the raw materials with three parameters namely time, quality of materials and the accurate number of materials. Responsiveness is the rapidity of supply system to provide products or respond in fulfilling the demands at the right time. Flexibility is the adjustment to the changes of demands or the needs that must be done quickly. While Cost includes materials, labours, equipments. Assets are the ownership of a company which can be used to meet the customers' desires.

There are six risks which will be evaluated by using metric system of model SCOR performance based on the results of six highest ranks of risk assessments. As a result of SCOR performance, there are two risks which can be categorized as Internal Facing and four risks as Customer Facing. Customer facing risks are risks that relate with suppliers that have risk categories as follows: Continuity of supply, on time delivery, Knowledge resource and Quality whereas Internal facing risks relate with buyers, and they are 
categorized as accident risks and knowledge resource. For further information, they are completely described in Table 7.

Table 7. Risk Evaluation based on SCOR Performance

\begin{tabular}{|c|c|c|c|c|c|c|}
\hline \multirow{3}{*}{ Risk Category } & \multirow{3}{*}{ Risks } & \multicolumn{5}{|c|}{ Performance Attribute } \\
\hline & & \multicolumn{3}{|c|}{ Customer Facing } & \multicolumn{2}{|c|}{ Internal Facing } \\
\hline & & $\begin{array}{l}\text { Reliabili } \\
\text { ty }\end{array}$ & $\begin{array}{l}\text { Responsiven } \\
\text { ess }\end{array}$ & Flexibility & Cost & Assets \\
\hline $\begin{array}{l}\text { Continuity of } \\
\text { supply }\end{array}$ & $\begin{array}{l}\text { The unavailability } \\
\text { of raw materials } \\
\text { needed by the } \\
\text { company }\end{array}$ & $\sqrt{ }$ & & & & \\
\hline Accident & $\begin{array}{lr}\text { The fire } & \text { of } \\
\text { warehouse } & \text { which } \\
\text { contains } & \text { raw } \\
\text { materials } & \end{array}$ & & & & & $\sqrt{ }$ \\
\hline $\begin{array}{ll}\text { On } & \text { time } \\
\text { delivery } & \end{array}$ & $\begin{array}{l}\text { Incompatibility of } \\
\text { time in delivering } \\
\text { all raw materials } \\
\text { with the previous } \\
\text { schedule }\end{array}$ & & $\sqrt{ }$ & & & \\
\hline $\begin{array}{l}\text { Knowledge } \\
\text { resource }\end{array}$ & $\begin{array}{l}\text { The occurrence of } \\
\text { planning fault on } \\
\text { raw materials need } \\
\text { Sudden changes on } \\
\text { materials planning }\end{array}$ & & & $\sqrt{ }$ & $\sqrt{ }$ & \\
\hline Quality & $\begin{array}{l}\text { Paper raw materials } \\
\text { received } \\
\text { blemished } \\
\text { spotted }\end{array}$ & $\sqrt{ }$ & & & & \\
\hline
\end{tabular}

Source: Supply Chain Council, 2006, Supply Chain Operations Reference Model, SCOR Version 8.0 Overview

Risk Mitigation to improve Supplier Performance. Risk Mitigation is carried out by preceding looking for the root of risk causes, so that a proposed correction for the root of risk causes can be given. Mitigation is carried out in order to minimize the potential risks.

Table 8. Risk Mitigation for Improving Supplier Performance

\begin{tabular}{llll}
\hline Risks & \multicolumn{1}{c}{ The Root of Causes } & \multicolumn{1}{c}{ Corrections } & \multicolumn{1}{c}{ Mitigations } \\
\hline $\begin{array}{l}\text { The unavailability of } \\
\text { raw materials needed } \\
\text { by the company }\end{array}$ & $\begin{array}{l}\text { The existence of } \\
\text { policy which } \\
\text { minimize the storage } \\
\text { of materials. }\end{array}$ & $\begin{array}{l}\text { Being more selective in } \\
\text { managing the materials, } \\
\text { means that the materials } \\
\text { stored are critical ones }\end{array}$ & $\begin{array}{l}\text { By having } \\
\text { Supplier } \\
\text { Relationship } \\
\text { Management } \\
\text { (SRM) approach. }\end{array}$ \\
$\begin{array}{l}\text { The fire of } \\
\begin{array}{l}\text { warehouse which } \\
\text { contains } \\
\text { materials }\end{array}\end{array} \quad \begin{array}{l}\text { Electric Short circuit, } \\
\text { the peeling cable }\end{array}$ & $\begin{array}{l}\text { Connecting the cable } \\
\text { according to the rules }\end{array}$ & $\begin{array}{l}\text { Checking the } \\
\text { electric cables } \\
\text { periodically }\end{array}$ \\
\hline
\end{tabular}


Handayani: Risk Management of Supplier-Buyer in Procurement of Raw Materials...

\begin{tabular}{lll}
\hline Risks & \multicolumn{1}{c}{ The Root of Causes } & \multicolumn{1}{c}{ Corrections } \\
\hline $\begin{array}{l}\text { Incompatibility of } \\
\text { time in delivering all } \\
\text { raw materials with } \\
\text { the previous schedule }\end{array}$ & $\begin{array}{l}\text { The delay in } \\
\text { delivering materials } \\
\text { to suppliers }\end{array}$ & Using inventory system \\
& & \\
& & \\
& & \\
The occurrence of & Stock in warehouse & $\begin{array}{l}\text { Recording the stocks of } \\
\text { planning fault on raw materials in the } \\
\text { materials need }\end{array}$ \\
is not real time & & warehouse so the \\
& & $\begin{array}{l}\text { beginning stocks and } \\
\text { ending stocks can be } \\
\text { real time. }\end{array}$ \\
& &
\end{tabular}

Sudden changes on materials planning
The changes of demand that are not in accordance with the sales plan

Raw materials of papers received are blemished spotted
Mitigations

a) Having

coordination

with supplier

by Sharing the information between buyer and supplier

b) Applying e-

SRM

(Electronic-

Supplier

Relationship

Management)

Controlling the recorded stocks of raw material in the warehouse is expected to reduce or eliminate the activities of checking the materials in the warehouse manually

Revising the Forecasting Improving data in which the sales planning data is based on the real demand coordination by sharing information among the distributors, marketing, and PPIC.

Taking the samples must be done correctly according to procedures
Improving the quality of raw materials from Suppliers and then the Suppliers should recheck the quality of raw materials before being delivered

Supplier Relationship Management (SRM) is one of the approaches in doing risk mitigations which focus on the beginning relationship in supply chain (Supplier -Buyer). By having relation/ supplier and buyer interaction, the performance can be improved by adding many attributes which affect the improvement of relation with the suppliers. SRM is part of business application of SAP Business Suite, that gives integrated solution to 
optimize the procurement of goods and services through e-Procurement process with web base.

SRM is superior in dividing suppliers into several segments, and they are generally based on the expenditure, value opportunities, dependency, risk to the product, and their complex services. Therefore it can measure the performance of each division openly and periodically, besides measuring the number of sales achievements, there must be some measurements for the quality of relationship such as integrity, good intention and respecting business procedures. By having SRM, hopefully the flexibility and the rapidity to respond the market changes and customers' expectations can be improved.

\section{DISCUSSION}

Supplier-buyer risks which mostly occur in Knowledge resource criteria that have the highest risks are the unavailability of raw materials needed by the company, the fire of warehouse which contains raw materials, incompatibility of time in delivering raw materials with the previous schedule. The three risks are evaluated based on the attribute of supplier performance and they include in reliability, responsiveness, and asset attributes. Suggested mitigations that have to be conducted in improving supplier performance as preventive steps of the company to manage the risks are by doing some approaches as follows: a) Having coordination with supplier by Sharing the information between buyer and supplier, b) Applying Supplier Relationship Management and e-SRM (Electronic- Supplier Relationship Management). Whereas the mitigation to internal buyer are a) Controlling the recorded stocks of raw material in the warehouse, b) Improving coordination by sharing information among the distributors, marketing, and PPIC, c) Checking the electric cables periodically.

\section{BIBLIOGRAPHY}

Anbanandam, R., Banwet, D. K. \& Shankar, R. (2011). Evaluation of supply chain collaboration: a case of apparel retail industry in India. International Journal of Productivity and Performance Management, 60 (2), 82-98.

Chopra, S., Sodhi, M.S. (2004). Managing Risk To Avoid Supply-Chain Breakdown, MIT Sloan Management Review, pp. 53-61

Elmuti Dean, William Minnis and Michael Abebe, (2008). Longitudinal Asesment of an integrated industrial supply chain, Supply Chain Management: An International Journal, hal 151-159

Faizal, Palaniappan (2014). Risk Assesment and Management in Supply Chain, Global Jurnal of Reseraches in Engineering Industrial Volume 14 Issue 2, pp 19-29

Handayani, Iryaning D., (2015). Seleksi Supplier Bahan Baku Dengan Pendekatan Multi Atribut Dicision Making, Jurnal PASTI, Volume 3 No 3 Bulan Agustus 2015, ISSN 2085-5869

Handayani, Iryaning D., (2016). “A Review: Mapping Potential Risks in Manufacturing Industry Supply Chain”, Industrial Spectrum Journal, 14 (1), April, ISSN 19636590 
Kayis, B. dan Karningsih, P. D. (2012). "SCRIS: A Knowledge Based System Tool for Assisting Manufacturing Organizations in Identifying Supply Chain Risks", Journal of Manufacturing Technology Management, 23 (7), 834-852.

Kusumadewi, S., Hartati, S., Harjoko, A. \& Wardoyo, R., (2006). Fuzzy Multi-Attribute Decission Making. 1 ed. Yogyakarta: Graha Ilmu.

Kleindorfer Paul R. dan Saad Germaine H., (2005). "Managing Disruption Risks in Supply Chains", Production and Operations Management POM. 14 (1), 53-68.

Liu Shuguang, Jun Lin dan Karen A. Hayes, (2010). "An agile and diversified supply chain: reducing operational risks", International Business Journal, 20 (3), 222-234.

Marhavilas, P.K., Koulouriotis, D.E., Mitrakas, C., (2011). "On the Development of a New Hybrid Risk Assessment Process Using Occupational Accidents' Data: Application on the Greek Public Electric Power Provider", Journal of Loss Prevention in the Process Industries, 24, 671-687.

Marimin et al. (2013). Fuzzy Decision Making Techniques and Analysis in Supply Chain Management, Bogor: IPB Press.

Punniyamoorthy, M. (2013). "Assessment of supply chain risk: scale development and validation", Benchmarking: An International Journal, 20 (1), 79-105.

Pujawan, N. (2010). Supply Chain Management, $2^{\text {nd }}$ edition, Guna Widya, Surabaya.

Ryu, I., So, S. \& Koo, C. (2009). The role of partnership in supply chain performance", Industrial Management \& Data Systems, 109 (4), 496 -514.

Salam, M. A. (2011). Supply chain commitment and business process integration", European Journal of Marketing, 45 (3), 358 - 382.

Schmidt William., Ananth Raman (2012). When Supply-Chain Disruptions Matter, Working Paper, January 3, 1-34

Segismundao, A., Miguel, P.A.C., (2008). FMEA in the context of risk management in new product development. A case study in an automotive company, International Journal of Quality and Reliability Management, 25 (9), 899-912.

Supply Chain Council, SCOR Version 8.0 Overview. 2006. www.supply-chain.org

Stevani Venska, dan Oki Sunardi . (2014). "The Role of Dependency, Commitment, Trust and Communication on Supply Chain Collaboration and Company Performance: Preliminary Study", Journal of Technology Management, 13 (3).

Tuncel G. dan Alpan G. (2010). "Risk Assessment and management for supply chain networks : A case study", Computers in Industry, 61, 250-259.

Trkman, P., McCormack, K., (2009). "Supply chain risk in turbulence environments-A conceptual model for managing supply chain network risk", International Journal of Production Economics, 119 (2), 247-258.

Ulfa Maria (2016). Design and Development of Refined Sugar Supply Chain Risk Management Model, Dissertation, IPB

Vanany, I., S. Zaelani, and Pujawan, N., (2009). "Supply chain risk management: literature review and future research". International Journal of Information Systems and Supply Chain Management, 2 (1), 16-33.

$\mathrm{Wu}, \mathrm{T} ., \mathrm{Blackhurst}, \mathrm{J}$. dan Chidambaram, V. (2006). "A model for inbound supply risk analysis", Computers in Industry, 57, 350-365.

Supply Chain Council. SCOR Version 8.0 Overview. 2006. www.supply-chain.org 